\title{
The Society Announces a New Fellowship
}

During recent years there has sprung up among the country's leading universities a demand for courses in the history of business enterprise in the United States. Americans are coming to realize that one of their country's greatest contributions to civilization has been in the field of business administration and technology. With that realization has come a desire to know something of the background and meaning of America's achievements in these fields.

Unfortunately the demand for professors qualified to teach Business History has already begun to outstrip the supply, since no concerted effort has ever been made to train men as specialists in the subject. For many years the Harvard Graduate School of Business Administration was the only place where Business History was taught; but usually students who were attracted to that institution were interested not in the teaching profession but in a career in business for which the history of business served only as a background. Even those who did graduate work in the field commonly stepped from college into the business world. As a result, when in recent years universities have wanted to institute a course in Business History, they have had either to delay such action until a suitable man could be found or else have had to induce someone in one of the allied social sciences to develop a course in the field.

The Business Historical Society, whose stated purpose is to "stimulate interest in the beginnings and evolution of finance, commerce, and industry," is undertaking by means of a Fellowship to encourage some promising student or assistant professor to equip himself to teach the subject of Business History in a college or graduate school. The Society hopes, by example and publicity, to interest others in the worth-while task of informing the collegiate segment of the nation of their business heritage. To this end the Council of the Society has recently voted to make a gift to Harvard University establishing a Fellowship in Business History that will enable a scholar to spend twelve months of study and research at the Harvard Graduate School of Busi- 
ness Administration. Although initially only one Fellowship is being offered, the Society anticipates that, if response seems to warrant it, the Fellowship may be reoffered in subsequent years, either by the Society itself or possibly by other groups similarly interested.

The stipend of the Fellowship will be made available in the following amounts:

To veterans $-\$ 2,500$ in cash.

To non-veterans - $\$ 2,500$ in cash, plus tuition.

Since the stipend will be given as an award of merit and not for services rendered, it will not be subject to the federal withholding tax; nor will it deprive a veteran of any government allowances to which he may otherwise be eligible. The Society has tried to make the Fellowship as attractive financially as possiblc so that men of advanced training will be induced to apply.

Applicants must have either a master's or a doctor's degree and must be interested in teaching the subject of Business History. Their field of specialization would typically have been either in American or Economic History or in Business Administration or Economics. They may, if they desire (and if they have not already received a doctor's degree) apply to the Doctoral Board of the Harvard Business School for permission to use their year of training while a Business History Fellow as part of their preparation for the degree of Doctor of Commercial Science. Such a request would, however, be a matter of personal negotiation between the applicant and the Doctoral Board and would not be a part of the Fellowship agreement.

A committee of three, appointed by the Dean of the Harvard Business School, will select from among the applicants the name of a candidate to be presented to the President and Fellows of Harvard University for approval. The Fellowship will be available in February, 1948, at the earliest, the starting time to be adjusted to suit the individual's convenience, within reasonable limits.

The Fellow will be expected to spend twelve months in research and study at the Harvard Business School, where he will become a regularly enrolled student. His research may be in a subject of his own choice, but it must be of sufficient quality and significance to warrant publication. As part of his training, a Fellow will be expected to take the School's courses in Business History 
and in Research in Business History. In addition he may take whatever other courses are necessary to further his understanding of the field in which he chooses to specialize.

Further information, application blanks, and printed circulars announcing the Fellowship may all be obtained by writing to the Executive Secretary of the Business Historical Society, Inc., Soldiers Field, Boston 63, Massachusetts.

\section{William Jones and His Unsuccessful Steam- boat Venture of 1819}

In connection with some research in the field of banking history the author recently came across the William Jones Papers, acquired a few years ago by the Historical Society of Pennsylvania. These records, which are of unusual interest in many respects, are the basis of the present essay. ${ }^{1}$

William Jones (1760-1831), as is generally known, was a Philadelphia shipping merchant and, during the War of 1812 , both Madison's Secretary of the Navy and Secretary of the Treasury pro tem. In 1816 he became, for political reasons, the first president of the second Bank of the United States, but he resigned as early as January, 1819, after an inefficient and unsuccessful administration. What William Jones did upon leaving the Bank has hitherto been unknown, but his papers show that he entered the then young field of steamboat building.

When he did so, steamboating and steamboat building had already reached a certain maturity. ${ }^{2}$ It will be remembered that

${ }^{1}$ The Historical Society of Pennsylvania has graciously permitted the use of the material reproduced herewith.

"For the early history of steamboat building and steamboating see the following: Robert G. Albion, The Rise of New York Port (New York, 1939), Chap. viII; James T. Flexner, Steamboats Come True. American Invento's in Action (New York, 1944); Henry Hall, Report on the Shipbuilding Industry of the United States, U. S. Tenth Census, vol. 8 (Washington, 1884); George B. Merrick and William R. Tibbals, "Genesis of Steam Navigation on Western Rivers" in Proceedings State Hist. Soc. of Wisconsin, 1911; George H. Preble, A Chronological History of the Origin and Development of Steam Navigation, 2d ed. (Philadelphia, 1895); Archibald D. Turnbull, John Stevens: An American Record (New York, 1928), Chaps. V-VI, IX-Xv, XIX. 